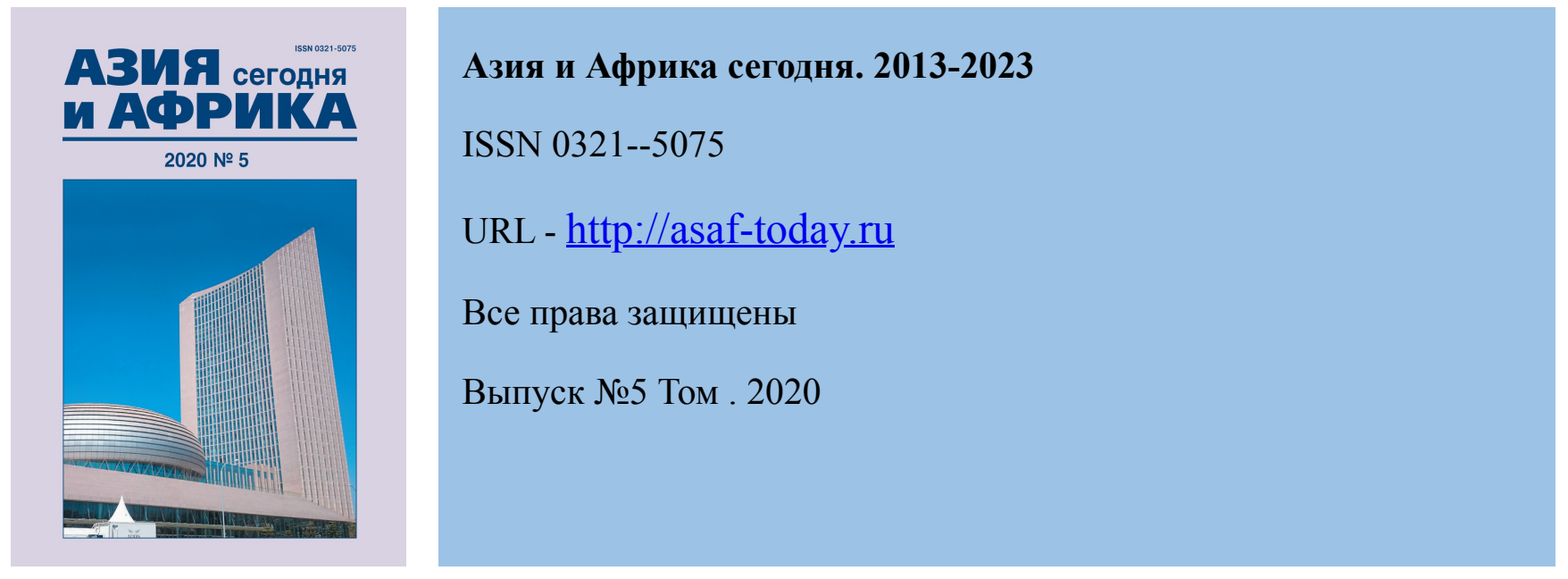

\title{
Uganda: the civil war and the destiny of a journalist
}

\author{
Денисова Татьяна Сергеевна \\ Институт Африки РАН \\ Москва, РФ, 123001, Москва, ул. Спиридоновка, 30/1 \\ Аннотация
}

Ключевые слова:

Дата публикации: 23.06.2020

Ссылка для цитирования:

Денисова Т. C. Uganda: the civil war and the destiny of a journalist // Азия и Африка сегодня. - 2020. - Выпуск №5 C. 63-65 . URL: https://asaftoday.ru/s032150750009553-0-1/. DOI: 10.31857/S032150750009553-0

1 The book by British journalist William Pike (William Pike. Combatants. A Memoir of the Bush War and the Press in Uganda. L.: 2019. 293 p.) is an important historical document that reveals details of numerous events of the Ugandan Civil War of 1981-1986, the post-war reconstruction, the ascent to power of Yoweri Museveni and the first years of his presidency. 


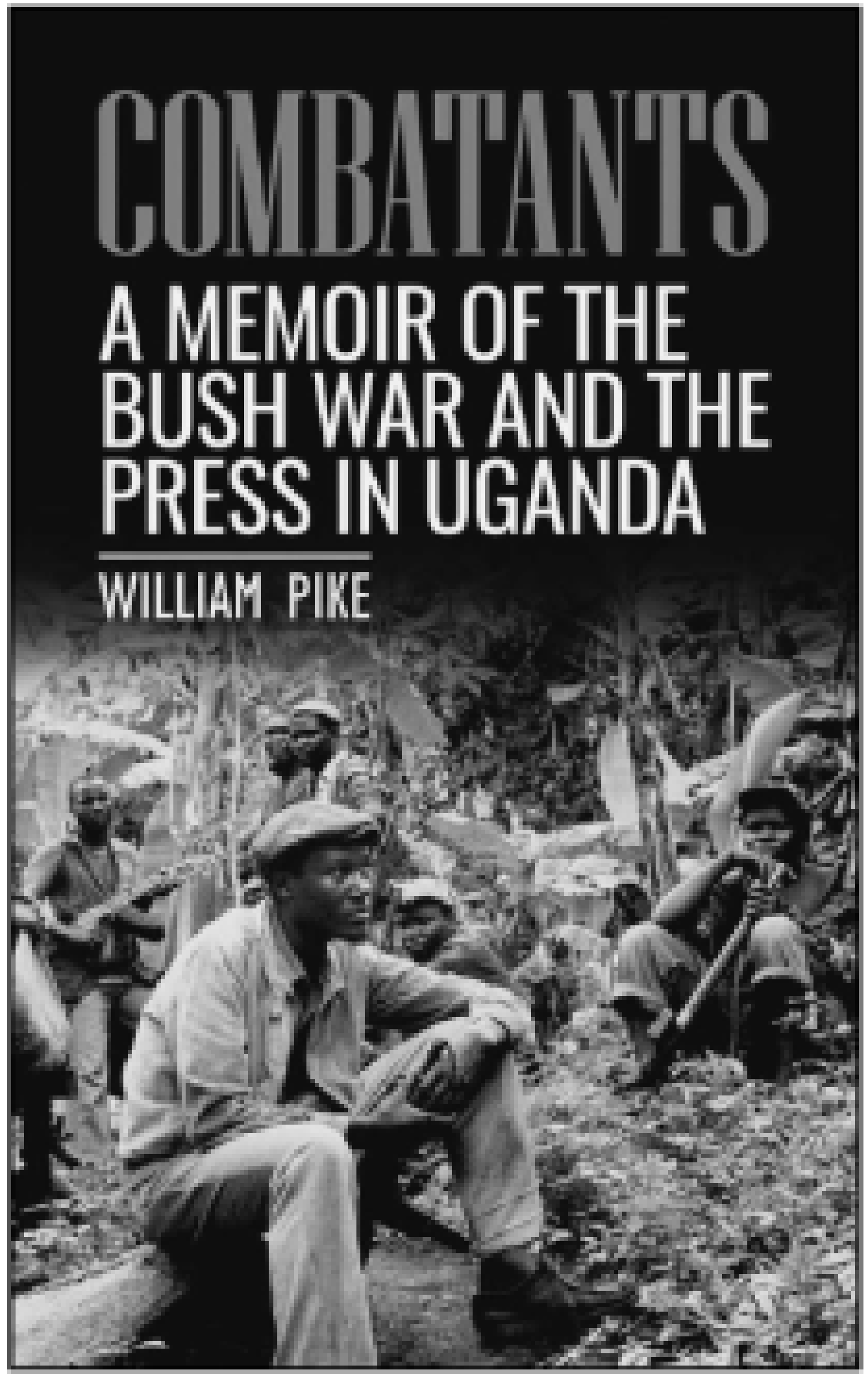

3 The work is especially valuable because the author did not just visit cantonment sites of the National Resistance Army (NRA), which had been established in 1981 and soon thereafter transformed into the National Resistance Movement (NRM, or simply the Movement), but also was the first journalist to interview the leader of the NRM - the future president of Uganda Yoweri Kaguta Museveni. 
4 The key characters of the book - field commanders of the Movement and W. Pike himself - are, undoubtedly, extraordinary personalities. Incidentally, the author's name should be familiar to the readers of the Asia and Africa today journal of the Russian Academy of Sciences due to the 2012 publication of the article «Mr. Pike in Uganda and Moscow» [1], authored by Dr. Oleg Teterin, who had meetings with the Englishman while being in charge of the Kampala bureau of the Novosti News Agency (1985-1990). In turn, W. Pike at that time was heading the editorial board of the Ugandan government newspaper New Vision.

5 Interestingly, the "African memoirs» of the Russian [2] and British journalists were published nearly simultaneously, allowing us to compare their views - in many respects similar - of events in the Uganda of those days ${ }^{1}$.

6 W. Pike has been taking interest in events taking place on the Black Continent throughout his life. And this is not surprising: the author was born on May 24, 1952 in Tanganyika (present-day Tanzania), where his father served as the Commissioner of the Southern Province. In 1959, his parents brought William to «cold, gray» England, and this was a traumatic experience for the boy. Even then he «knew that he would return to Africa» (p. 5). In 1982, Pike arrived as a freelance journalist in Tanzania, and in July 1984, he came to Uganda.

Meanwhile, events in Uganda at that time were developing rapidly. The failure of the 1972 military operation against Idi Amin, which had been launched from the Tanzanian territory, prompted Y. Museveni to form his own movement - the Front for National Salvation (FRONASA), whose fighters underwent training in Mozambique. In 1978, as a result of a military operation carried out by Ugandan rebel groups and units of the Tanzanian army, the rigidly authoritarian regime of Idi Amin collapsed, and Museveni became the youngest member of the presidential administration of Yusuf Lule (1979), and then - of President Godfrey Binaisa (1979-1980). In 1980, a presidential election took place, wherein Milton Obote rigged the voting results and claimed victory. Museveni, who had warned Obote in advance that he would not allow falsification, began an armed struggle against the ruling regime of Obote and established the NRA/NRM [5].

8 In 1982-1983, the NRM operated on the territory of the so-called Luweero Triangle, formed by several roads about 120 miles north of Kampala. In 1981-1985, about 300 thousand people died in the area as a result of armed clashes, and Pike, seriously concerned with the fact that Western press was ignoring these events, decided to fill the gap and tell the world about the abuses of Obote's regime, the goals and objectives of the rebels, and the situation in Uganda in general (p. 20).

9 Almost immediately after arriving in Kampala in 1984, with the support of the Ugandans whom he had met in London, Pike went to the area occupied by the rebels. Risking his life, accompanied by just one NRM fighter, the journalist crossed government army checkpoints, travelled kilometers of forest paths in total darkness or moonlight, got stuck in a swamp, waded through bushes, going from one rebel base to another.

10 Of special value for the readership, in particular for scholars in conflict studies, are the detailed descriptions of NRM camps a few kilometers from Kampala: plastic 
canopies with beds arranged under them, bonfires for cooking, AK-47 rifle pyramids, observation posts... (p. 35). According to Pike, the area, including villages with huts destroyed during the war, seemed completely uninhabited to him and reminded of the film Stalker by Andrei Tarkovsky, wherein the hero first crosses an abandoned industrial zone in one direction and then in another direction (p. 37).

11 Pike rightly notes the absence of tribal divisions in the Movement, in which representatives of many Ugandan ethnic groups participated. He points to the discipline of the militants, their loyal attitude to local residents - regardless of their willingness or unwillingness to help the NRM. The author compares the behavior of rebels and soldiers of the regular army: the former, having taken prisoners, offered them either to join the Movement or to walk free; the latter killed the enemy on the spot. Thus, Pike emphasizes the difference between Museveni's fighters and not just Obote's soldiers, but also participants of other African rebellions (the United Revolutionary Front in Sierra Leone, the Liberian National Patriotic Front, the Lord's Resistance Army in Uganda, etc.), which were distinguished by extreme cruelty.

12 Pike notes that the success of the NRM was largely due to the support rendered to it by the local population, in particular the provision of information on the movement of the regular army. That is why the rebels often managed to show initiative and successfully repel attacks of the government army or, on the contrary, carry out unexpected attacks, forcing Obote's troops to withdraw from their positions, leaving behind their dead and wounded. However, as the author points out, the soldiers would later brutally punish the civilian population. Pike, while celebrating military successes of the NRM, fails to explain how the rebels defended the locals from the revenge of Obote's soldiers.

13 The most interesting part of Pike's book is dedicated to his June 1984 meeting with the opposition leader Y. Museveni at a rebel forest base. The journalist tells how one morning a group of soldiers led him to the hut where their leader lived. The future president was sitting on a folding wooden chair, benches stood around him in rows, field commanders were sitting on the benches and discussing the strategy and tactics of the war. Museveni was dressed in a camouflage military uniform over a white T-shirt and high canvas shoes, looked calm and was fuller than in the photographs made 3-4 years earlier (p. 59).

14 They talked all day. Museveni said that the NRM had three thousand soldiers fighting against the regular army of almost 40 thousand. Obote's soldiers, however, «deserted at the first opportunity» (p. 60). Furthermore, the Movement controlled 7 thousand square miles of territory, and this was one of the reasons for its success: militant camps were scattered over a vast area and were hard to find in the bush. However, as Pike notes, quoting Museveni, what matters most was not territorial control, but the self-preservation of the Movement, which had to exhaust the enemy with short sorties, seizure of weapons and destruction of the regime's political image (p. 61).

15 Pike highlights some features of the NRM's activity that distinguished it from other African rebel movements, usually based in peripheral areas, while Museveni's Movement waged war just a few miles away from Kampala: being near the capital, the rebels could create more problems for the authorities, thus reducing the duration of 
hostilities. Theoretically, one can agree with this, but the Ugandan Civil War lasted five years, and for such a small country as Uganda, this is a long time.

16 As the author notes, it is unusual for Africa to wage a rebel war without external assistance. In fact, the Movement was supported only by Libya: Muammar Gaddafi sent weapons to Museveni and provided other logistical assistance to the NRM however, on a limited scale. The Obote government, on the other hand, relied on the assistance from the UK, Egypt, Sudan, other countries and the IMF.

17 Having returned in 1985 from Uganda to the UK, Pike tried to draw the attention of the British authorities to the situation in the country, to the corrupt and repressive nature of Obote's regime, but to no avail. Meanwhile, the journalist became increasingly involved in the affairs of the NRM, attended, and sometimes spoke at rallies of supporters of the Movement in London.

18 On July 27, 1985, during Pike's stay in the UK, a military coup led by General Tito Okello Lutwa took place in Uganda. Okello invited all opposition groups to cease hostilities and join the government of national unity. However, as government forces continued to commit atrocities in rural areas, Museveni decided to continue the struggle. In January 1986, the NRM launched an attack on Kampala, on January 26 the rebels stormed the capital, and on January 29 Museveni was proclaimed president of the country.

19 In July 1986, Pike's old friends - former leaders of the NRM, who were now holding various positions in the new government bodies - invited him to head the New Vision newspaper, and the journalist returned to Uganda. He faced an insurmountable task: the newspaper was published irregularly due to the lack of personnel, finances, and premises. However, Pike was enthusiastic: running a newspaper allowed to do a lot of good for the country, at least by conveying the truth to its inhabitants.

20 The author describes in detail both the successes of New Vision, which has become one of the most popular periodicals in the country, and the failures and even conflicts with the authorities due to the newspaper's criticism of various aspects of the government's economic policy. According to Pike, the process of economic recovery turned out to be much more complicated than Museveni had thought during the war. The Ugandan leader believed that the economy would begin to develop rapidly as soon as the political situation in the country stabilized. Pike's disappointment with Museveni, which for several years had been his idol, can be read between the lines. However, in fairness, it should be noted that the Ugandan leader apparently did not expect that he would inherit from the previous regimes the economy that had been so badly damaged as a result of war and poor management: closed industrial enterprises, impassable roads, dormant bureaucracy, depreciated currency, etc.

21 The author notes the many positive changes were observed in the early years of Museveni's rule: new schools were built, roads were repaired, a local government system was created, and the army was strengthened. However, in the context of political (conflicts with the LRA, the kingdom of Buganda, etc.) and economic instability, the transformation of the regime in the direction of «tightening the screws» seemed inevitable. Since the mid-1990s, the authoritarian tendencies of Museveni's regime, which has been solidifying its power, first, by removing influential public figures from 
the process of political decision-making and, second, by establishing tight control over the opposition, have become increasingly apparent.

22 Pike rightly stresses that Museveni's dynamism has certainly contributed to the implementation of radical political transformations, but the lack of political and civil liberties has remained a serious problem facing the country. Indeed, the NRM was formed as a rebel movement, and during the first years of peace in the post-war country the «temporary» ban on the activities of political parties and the neutralization of the opposition and various radical groups seemed justified, because economic reforms could only be carried out in peace and stability. However, over time, the hegemony of the Movement as the only legitimate political force lost its necessity, but the persecution of dissidents even intensified. Repression also affected journalists. Some independent or claiming to be independent media were shut down.

23 One day in the fall of 1989, at a regular press conference, Museveni, turning to Pike, declared: «Bwana Pike, I am not happy with you and your paper» (p. 243). In 2006, Museveni accused the journalist of working for MI6 (p. 263). However, Pike continued to lead New Vision until October 2007, when he decided not to tempt fate and, not waiting for his dismissal or more severe punishment, moved to Nairobi to start publishing the Star newspaper for Kenya's Radio Africa Group...

\section{Примечания:}

1. In 2011, William kindly provided his long-time friend Oleg with one of the chapters of his future book, Meeting Museveni, a Russian translation of which was consequently published in the Asia and Africa today journal [3], and in 2012 he facilitated the publication of Dr. O. Teterin's article about the first day of the July 27, 1985 coup in Kampala in the New Vision newspaper. Moreover, the article was included in the «Golden Jubilee» rubric as one of the brightest witness accounts in the history of independent Uganda [4].

\section{Библиография:}

1. Teterin O.I. 2012. Mr. Pike in Uganda and Moscow. Asia and Africa today. № 3, pp. 62-67. (In Russ.)

2. Teterin O.I. Remembering Africa (important issues... and not so much). Moscow, 556 p. (In Russ.)

3. William Pike. 2012. Meeting Museveni. Asia and Africa today. № 3, pp. 68-72. (In Russ.)

4. Teterin O.I. How Swahili saved a Russian diplomat during the 1985 coup. New Vision (Kampala). August 28, 2012.

5. Denisova T.S. 2016. Uganda: Yoweri Museveni and the problem of political longevity. Asia and Africa today. № 11, pp. 34-41. (In Russ.) 


\section{Uganda: the civil war and the destiny of a journalist}

\section{Tatyana S. Denisova}

Institute for African Studies, RAS

Moscow, Russian Federation

Abstract

Keywords: William Pike, Uganda, rebels, mass media, National Resistance Movement, National Resistance Army, Yoweri Museveni

Date of publication: 23.06 .2020

\section{Citation link:}

Denisova T. Uganda: the civil war and the destiny of a journalist // Asia and Africa Today. - 2020. - Issue 5 C. 63-65 . URL: https://asaf-today.ru/s032150750009553-0-1/. DOI: $10.31857 / \mathrm{S} 032150750009553-0$ 